\title{
Next-generation sequencing reveals three novel variants in Polish patients with Usher syndrome
}

\author{
Nowe mutacje wykryte u pacjentów z zespołem Ushera przy użyciu techniki \\ sekwencjonowania następnej generacji
}

\author{
Anna Wawrocka', Joanna Walczak-Sztulpa', Anna Skorczyk-Werner', tukasz Kuszel', \\ Magdalena Socha', Aleksander Jamsheer,', Maciej R. Krawczynskii ${ }^{1,2}$ \\ Department of Medical Genetics, Poznan University of Medical Sciences, Poland \\ Head: Professor Anna Latos-Bielenska, PhD, MD \\ 2 Centers for Medical Genetics GENESIS, Poznan, Poland \\ Head: Professor Anna Latos-Bielenska, PhD, MD
}

Abstract: $\quad$ Aim: Usher syndrome is an autosomal recessive disorder which manifests as sensorineural hearing impairment with retinitis pigmentosa and, in some cases, also vestibular dysfunction.

Material and methods: We studied the molecular basis of the disease in seven unrelated Polish patients with Usher syndrome. Patients underwent audiologic and ophthalmic examination. Next-generation sequencing on the diagnostic panel for Usher syndrome was performed in all patients.

Results: Next-generation sequencing enabled identification of mutations on both alleles in five patients (71.4\%). We describe three novel potentially pathogenic variants: c.14219G>T (p.(Gly4740Val)) in the GPR98 gene, c.5206_5207insC (p.(Lys$\left.\left.1737 \mathrm{Glnfs}{ }^{*} 28\right)\right)$ in the MY07A gene and c.11780A $>\mathrm{G}$ (p.(Asp3927Gly)) in the USH2A gene. In one patient, we identified two variants in two different genes: GPR98 and USH2A.

Conclusions: Our results expand the mutational spectrum associated with Usher syndrome by a description of three novel likely pathogenic alterations and support the use of targeted next-generation sequencing in genetic diagnosis of patients with this syndrome.

Key words: $\quad$ Usher syndrome, next generation sequencing, USH2A, GPR98, MYO7A genes.

Ahstrakt: $\quad$ Cel: przeprowadzenie analizy molekularnej w celu potwierdzenia klinicznego rozpoznania zespołu Ushera u siedmiu polskich pacjentów.

Materiał i metody: prezentujemy siedmioro pacjentów z niespokrewnionych ze sobą rodzin, którzy chorują na zespót Ushera. Przeprowadzono u nich badania audiologiczne i okulistyczne. Sekwencjonowanie następnej generacji na panelu dedykowanym dla zespołu Ushera wykonano u wszystkich pacjentów.

Wyniki: badanie molekularne za pomocą sekwencjonowania następnej generacji pozwoliło na wykrycie mutacji na obu allelach u pięciorga z siedmiorga pacjentów (71,4\%). Opisaliśmy trzy nowe, potencjalnie patogenne, warianty: c.14219G >T (p.(Gly4740Val)) w genie GPR98, c.5206 5207insC (p.(Lys1737GInfs*28)) w genie MY07A i c.11780A > G (p.(Asp3927Gly)) w genie USH2A. U jednego pacjenta zidentyfikowaliśmy dwa warianty w dwóch różnych genach: GPR98 i USH2A.

Wnioski: wyniki naszych badań poszerzają spektrum mutacji znanych dla zespołu Ushera, jednocześnie wskazują na zasadność stosowania metody sekwencjonowania następnej generacji w diagnostyce pacjentów z tym zespołem.

Słowa kluczowe: zespół Ushera, sekwencjonowanie następnej generacji, geny: USH2A, GPR98, MYO7A.

The authors declare no conflict of interest/ Autorzy zgłaszają brak konfliktu interesów w związku z publikowaną pracą

\section{Introduction}

Usher syndrome (USH) is an autosomal, recessively inherited condition, which manifests as deafness, retinitis pigmentosa (RP) and, in some cases, vestibular dysfunction. The prevalence has been estimated from 1/ 6000 to $1 / 25000$ (1). There are three clinical subtypes classified by the severity and onset of hearing loss and retinitis pigmentosa. USH1 is the most severe form, characterized by congenital severe to profound deafness and prepubertal onset of RP. Furthermore, children also have vestibular areflexia and absent vestibular function. Seven genes associated with this form have been identified: MYO7A, CDH23, PCDH15, USH1C, USH1G, CIB2 and ESPN (2-5). USH2 is a more frequent type, which manifests as congenital, mild to profound hearing loss, RP in the first or second decade of life and normal vestibular function. Three genes associated with this form have been described: USH2A, GPR98 and DFNB31 (4, 6-8). USH3 is the less common form of Usher syndrome, which manifests as progressive hearing loss, usually with the post-lingual onset as well as variable age of onset of visual loss and variable vestibular dysfunction (9). Two causal genes have been identified: CLRN1 and HARS (10-12).

We utilized targeted next-generation sequencing (NGS) to find disease-causing sequence variants in seven patients affected with Usher syndrome, demonstrating a high variant detection rate with this method. 


\section{Methods}

\section{Clinical studies}

Seven patients from unrelated Polish families (one patient from each family) manifesting clinical features of Usher syndrome participated in this study. Their parents did not show any symptoms of USH syndrome or other ocular symptoms. The patients received genetic counseling with detailed medical data analysis. Ocular assessment including central visual acuity measurement, fundus examination, electroretinography (ERG) and optical coherence tomography (OCT) was performed. Pure tone audiometry (PTA) was performed in all patients. One patient (p5) underwent neuro-imaging with high-resolution MRI to exclude brain and inner ear malformations. All patients agreed to participate in the study and to use their anonymized data in the publication. This study conforms to the Helsinki declaration and was approved by the Poznan University of Medical Sciences Institutional Review Board. Informed consent was obtained from them prior to molecular testing.

\section{Molecular genetic analysis}

Blood samples were collected and genomic DNA was extracted from peripheral blood leukocytes using the salting-out method. NGS with Illumina NextSeq on the diagnostic panel for Usher syndrome (Asper Biotech, Tartu, Estonia) was performed in all patients. A panel of 20 genes including $A B H D 12, C D H 23, C I B 2$, CLRN1, COL4A6, DFNB31, DSPP (excluding exon 5), GIPC3, GPR98, HARS, KARS, LHFPL5, LOXHD1, MYO7A, PCDH15, PDZD7, TNC, USH2A, USH1C and USH1G was analyzed. The read depth of the tested genes included in the panel was between 70-120x. The sequences were verified by comparing them to the human reference sequence of the GPR98 gene (NM_032119.4), MYO7A (NM_001127180.1) and USH2A (NM_206933.2) genes. The identified sequences variants were referred to the Human Gene Mutation Database (HGMD), the Exome Variant Server (NHLBI Exome Sequencing Project ESP), the 1000 Genomes Project database (1000 Genomes Project Consortium 2012) and ExAC Browser Beta (Exome Aggregation Consortium 2015). The in silico analyses using SIFT, PolyPhen-2 and MutationTaster 2 software were performed to predict the possible effect of the novel missense variants. The evolutionary conservation of nucleotide positions was analyzed by PhyloP and GERP ++ scores. To predict the impact of substitution between amino acids, the Grantham score was analyzed. Novel variants identified in this study were classified according to the American College of Medical Genetics and Genomics and the Association for Molecular Pathology (ACMG) guidelines (13). A control cohort of 100 healthy, ethnically matched individuals from the Genetics Department of Poznan University of Medical Sciences database, was used to verify novel variants identified in this study. Segregation analysis for the presence of altered alleles was performed in the families (families 1,2,3) with the novel potentially causative variants in GPR98, MYO7A and USH2A genes by Sanger sequencing of the appropriate exons (Fig. 1).

\section{Results}

The diagnosis was based on clinical, audiometric and ophthalmic data. Patients were identified as having USH1 and USH2 type according to the clinical features. The audiometric test demonstrated a congenital, bilateral hearing loss ranging from moderate to severe in the USH2 patients. In a USH1 patient (p2), deafness was defined as bilateral and profound, and was reported to be present in infancy. Parents of a p2 patient reported that the gait and balance problems were present from early childhood. All patients presented with typical signs and symptoms of RP, including night blindness, visual field narrowing, bone spicule-like pigmentation, retinal vessel attenuation and optic disc pallor. Furthermore, in three patients ( $1, \mathrm{p} 5$ and p6) cystoid macular edema (CME) was diagnosed. The clinical data has been shown in Table I. An example of typical ERG, OCT and audiometric findings (sourced from the patient p3) are presented in Figure 2.

\section{Molecular results}

In our cohort of seven patients diagnosed with USH, mutations in a compound heterozygous state were identified in five patients (71.4\%) while in two patients ( $p 5$ and p7) only one mutated allele was identified. Three novel variants were detected in three different genes (Tab. I).

In patient $\mathrm{p} 1$ the NGS revealed a novel missense variant c.14219G $>\mathrm{T}$ (p.(Gly4740Val)) and a known nonsense mutation c.7669C>T (p.Gln2557*) in the GPR98 gene (Fig. 1a., b.). The novel variant was predicted to be probably damaging by in silico analyses (Tab. I). Patient p2 is a compound heterozygous for a previously reported nonsense mutation c.5392C $>\mathrm{T}$ (p.Gln1798*) and a novel frameshift insertion c.5206_5207insC (p.(Lys1737Glnfs*28)) in the MY07A gene (Fig. 1c., d.).

In patient p3 a novel variant c.11780A $>$ G (p.(Asp3927Gly)) and one known mutation c.775_776delAG (p.Ser259Phefs*63) in the USH2A gene (in a heterozygous status) were identified (Fig. 1e., f.). In silico analysis of the missense substitution p.(Asp3927Gly) by PolyPhen2 and Mutation Taster 2 software showed that this variant is predicted to have a deleterious effect on usherin protein, while analysis by SIFT software indicated that this substitution is tolerated. PhyloP and GERP ++ score showed that nucleotide positions of the novel missense substitutions identified in patients p1 and p3 are evolutionarily conserved (Tab. I). None of the novel variants identified in this study was listed in the used databases. Furthermore, these variants were not detected in 100 control individuals from our in-house database.

Two known variants c.2299delG (p.Glu767Serfs*21) in USH2A and c.12704A $>$ G (p.Tyr4235Cys) in the GPR98 gene were identified in patient $\mathrm{p} 4$. In two patients ( $\mathrm{p} 5$ and $\mathrm{p} 7$ ), a known heterozygous variant in the USH2A gene was detected: c.11864G $>$ A (p.Trp3955*), while the second allele remained undetermined. Finally, patient $\mathrm{p} 6$ had two different known mutations, c.9676C > T (p.Arg3226*) and c.9424G > T (p.Gly3142*), in the USH2A gene. All detected variants in USH patients are summarized in table I. Segregation analysis of novel variants performed in their healthy parents revealed that they segregate with the phenotype according to the autosomal recessive mode of inheritance (Fig. 1).

\section{Discussion}

Here we report the results of targeted NGS of seven Polish patients with USH1 and USH2. Genetic background of the disease was identified in $71.4 \%$ patients with USH, which is consistent with the findings of other studies using the NGS method $(14,15)$. Patient examinations demonstrated audiometric and ophthalmic findings typical for Usher syndrome. Molecular studies confirmed 
Family 1

M1: GPR98 c.7669C>T

M2: GPR98 c.14219G>T
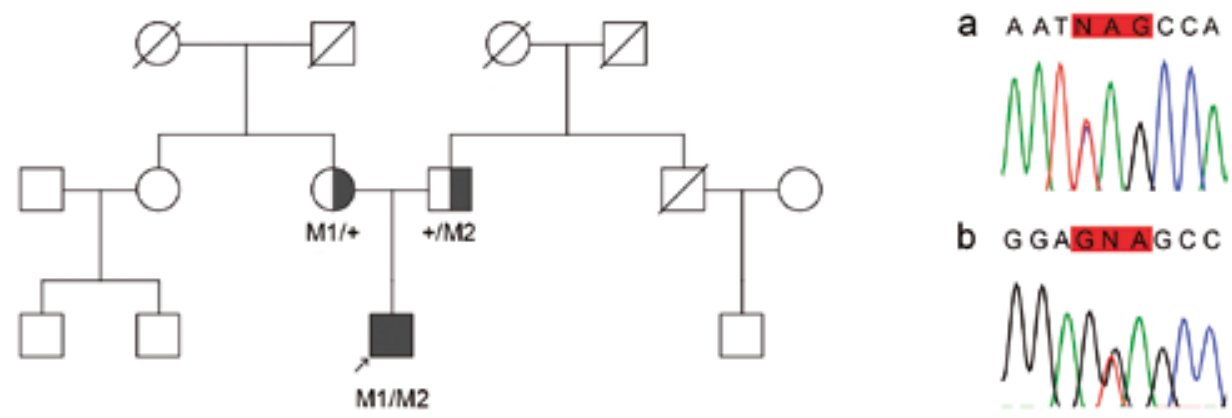

\section{Family 2 \\ M3: MYO7A c.5206_5207insC \\ M4: MYO7A c. $5392 \overline{\mathrm{C}}>\mathrm{T}$}

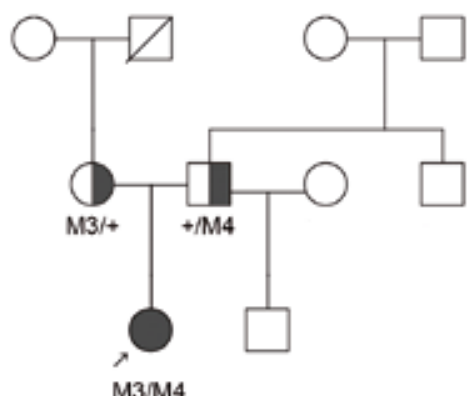

C GACNAGAT C

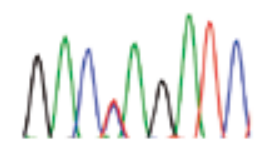

d TCCNANGN N

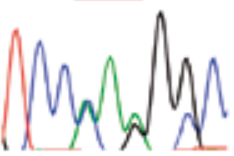

\section{Family 3}

M5: USH2A c.775_776delAG

M6: USH2A c. $117 \overline{80} \mathrm{~A}>\mathrm{G}$

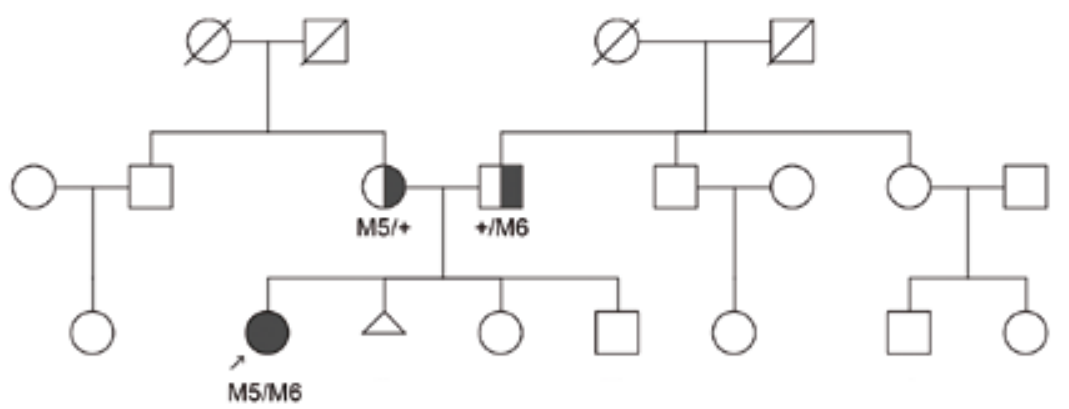

e CAGNNNNNN

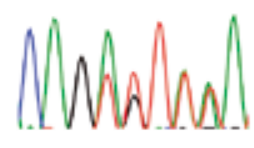

f AT G GNTIGAA

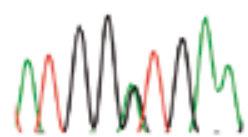

Fig. 1. Pedigrees and sequencing results with chromatograms for USH patients with novel variants. Pedigrees - the genotypes are provided for all subjects available for molecular genetic analysis. The black square and circles represent affected males and females respectively. White squares and circles represent unaffected family members. Triangle represents a miscarriage. Arrows point to probands. M1, M2, indicate variants detected in GPR98 gene (family 1), M3, M4, indicate variants detected in MYO7A gene (family 2), M5, M6 indicate variants detected in USH2A gene (family 3). Patient parents are asymptomatic carriers of the identified mutations. Chromatograms $-a$. b. Sequence variants detected in patient $\mathrm{p} 1$ in the GPR98 gene. a. c.7669C $>T\left(p . G \ln 2557^{*}\right)$. b. Novel variant c.14219G $>$ T, p.(Gly4740Val). c. d. Sequence variants detected in patient p2 in the MY07A gene. c. c.5392C > T (p.Gln1798*). d. Novel variant c.5206_5207insC, p.(Lys1737Glnfs*28). e. f. Sequence variants detected in patient $p 3$ in the USH2A gene. e. c.775_776delAG (p.Ser259Phefs*63). f. Novel variant c.11780A>G, p.(Asp3927Gly).

Ryc. 1. Rodowody oraz chromatogramy pacjentów z nowymi zidentyfikowanymi wariantami sekwencji. Rodowody - genotypy przedstawione u pacjentów dostępnych do badań. Czarne kwadraty oraz koła przedstawiają odpowiednio chorych mężczyzn i kobiety. Białe symbole oznaczają zdrowych członków rodziny. Trójkąt oznacza poronienie. Strzałki wskazują probandów. M1, M2 oznaczają warianty sekwencji zidentyikowane w genie GPR98 w rodzinie 1. M3, M4 oznaczają warianty sekwencji zidentyfikowane w genie MYO7A w rodzinie 2. M5, M6 oznaczają warianty sekwencji zidentyikowane w genie USH2A w rodzinie 3. Rodzice pacjentów są bezobjawowymi nosicielami mutacji zidentyfikowanych u dzieci. Chromatogramy - a. b. warianty sekwencji zidentyfikowane u pacjenta p1 w genie GPR98, a. c.7669C >T (p.Gln2557*). b. nowy wariant c.14219G >T, p. (Gly4740Val). c. d. warianty sekwencji zidentyfikowane u pacjenta p2 w genie MY07A c. c.5392C >T $\left(p . G \ln 1798^{*}\right)$. d. nowy wariant c.5206_5207insC, p.(Lys1737Glnfs*28). e. f. warianty sekwencji zidentyfikowane u pacjenta p3 w genie USH2A. e. c.775_776delAG (p.Ser259Phefs*63). f. Nowy wariant c.11780A >G, p.(Asp3927Gly). 


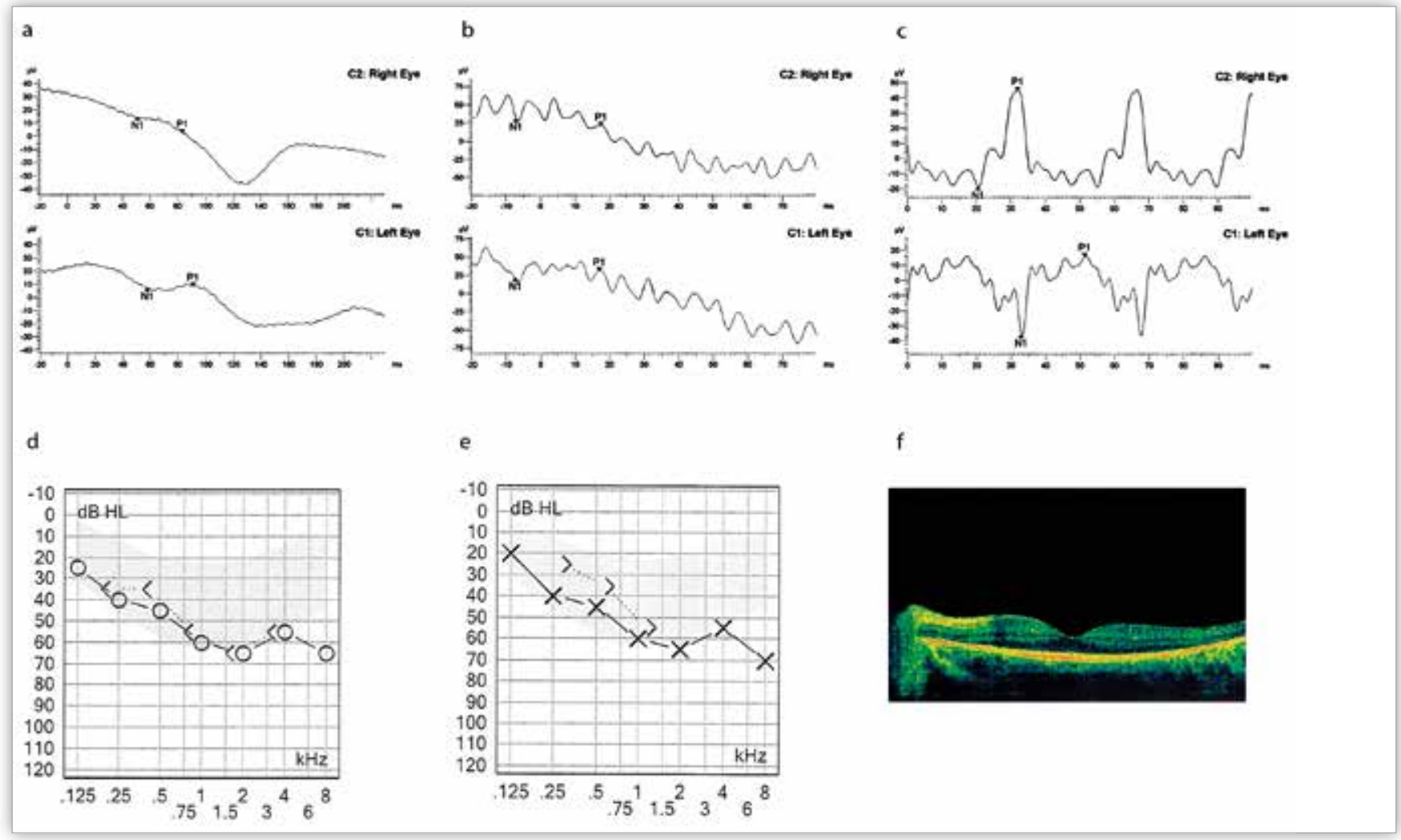

Fig. 2. Clinical findings of the patient $\mathrm{p} 3$ with mutations in USH2A gene, a, b, c severely abnormal scotopic white flash, scotopic and photopic white $30 \mathrm{~Hz}$ flicker electroretinograms (ERG) respectively, $d$, e audiograms: $d$ - right ear, e - left ear, cross or circle labels indicate air-conduction hearing, right angle labels indicate bone-conduction hearing, $f-$ optical coherence tomogram (OCT) showing a mild foveal hypoplasia.

Ryc. 2. Wyniki badań klinicznych u pacjenta $\mathrm{p} 3 \mathrm{z}$ mutacjami w genie USH2A, a, b, c znacznie obniżone zapisy ERG błyskowego, skotopowego oraz flicker $30 \mathrm{~Hz}$, d, e audiogramy: d - prawe ucho, e - lewe ucho, krzyżyki lub kółka oznaczają przewodnictwo powietrzne, symbol kąta oznacza przewodnictwo kostne, $\mathrm{f}$ - optyczna koherentna tomografia dna oka (OCT) wskazuje na łagodną hipoplazję dołka.

the clinical classification of the patients, USH2 with variants detected in the USH2A and GPR98 genes and USH1 with a variant in the MYOTA gene. Despite a small sample size, we observed that the most frequent sequence variants in USH2 patients were identified in the USH2A gene (7 out of 9 variants in USH2). The results are consistent with the previous studies indicating that mutations in this gene are the most common cause of USH2 $(16,17)$.

Two mutated alleles were identified in five out of seven patients. We detected three novel variants c.14219G $>$ T in the GPR98 gene, c. $11780 \mathrm{~A}>\mathrm{G}$ in the USH2A gene and c.5206_5207insC in the MY$07 A$ gene. A novel missense variant $c .14219 \bar{G}>T$ (p.(Gly4740Val)) in exon 70 of the GPR98 gene (p1) changes glycine to valine, both nonpolar amino acids, at amino acid residue 4740 that is highly conserved among species. Frameshift variant detected in one patient (p2), c.5206_5207insC (p.(Lys1737GInfs*28)), located in exon 38, leading to a stop codon 28 amino acid downstream, causes premature termination of translation. A novel missense variant c. $11780 \mathrm{~A}>\mathrm{G}$ identified in exon 61 of the USH2A gene (p3) (p.(Asp3927Gly)) is located in the fibronectin type 3 domain, which is involved in cell adhesion, its morphology, migration, thrombosis and embryonic differentiation. In one patient (p4), we identified heterozygous known variants in two different genes GPR98 and USH2A. A pathogenic frameshift variant c.2299delG in USH2A has been previously reported in USH patients. A missense substitution c. $12704 \mathrm{~A}>\mathrm{G}$ in the GPR98 gene is a very rare variant (allele frequency based on ExAC is 0.0001968 ), which was predicted to be probably damaging by in silico analyses. The GERP score of 4.45 indicated that nucleotide position 12704 of the identified change p.Tyr4235Cys was likely damaging. The Grantham score of 194 means that Tyrosine and Cysteine are evolutionarily very distant from each other. Therefore, their substitution is predicted to be more damaging. The two detected trans-heterozygous variants are present in two genes, on two different chromosomes. Both genes are known to cause USH2. In view of all these results, the two detected variants may be considered pathogenic in this patient. Digenic inheritance in ciliopathies like Usher syndrome and Nephronophthisis has been reported previously $(4,18,19)$. Digenic inheritance of $C D H 23$ and $P C D H 15$ has been shown to cause Usher syndrome type I in humans (20). As the presence of two additional variants in yet undiscovered USH genes, intragenic deletion or duplication cannot be excluded in the patient in question, further studies, especially in animal models, are required in order to confirm our assumptions of digenic inheritance in our patient. Many studies suggest that copy number variants can be significant USH2A mutations type that are missed by sequencing assays $(14,21,22)$. In the molecular analysis performed by Austin-Tse et al. in a group of 700 patients with hearing loss, copy number variants were identified in a significant proportion of the USH patients with a previously detected heterozygous variant only (23).

In our cohort, we were unable to detect the second putative mutation in two patients, who were positive only for heterozygous mutations. This can most likely be explained by technical limitations of targeted sequencing. The panel sequencing is designed to target the coding sequence and exon-intron borders. For deep- 


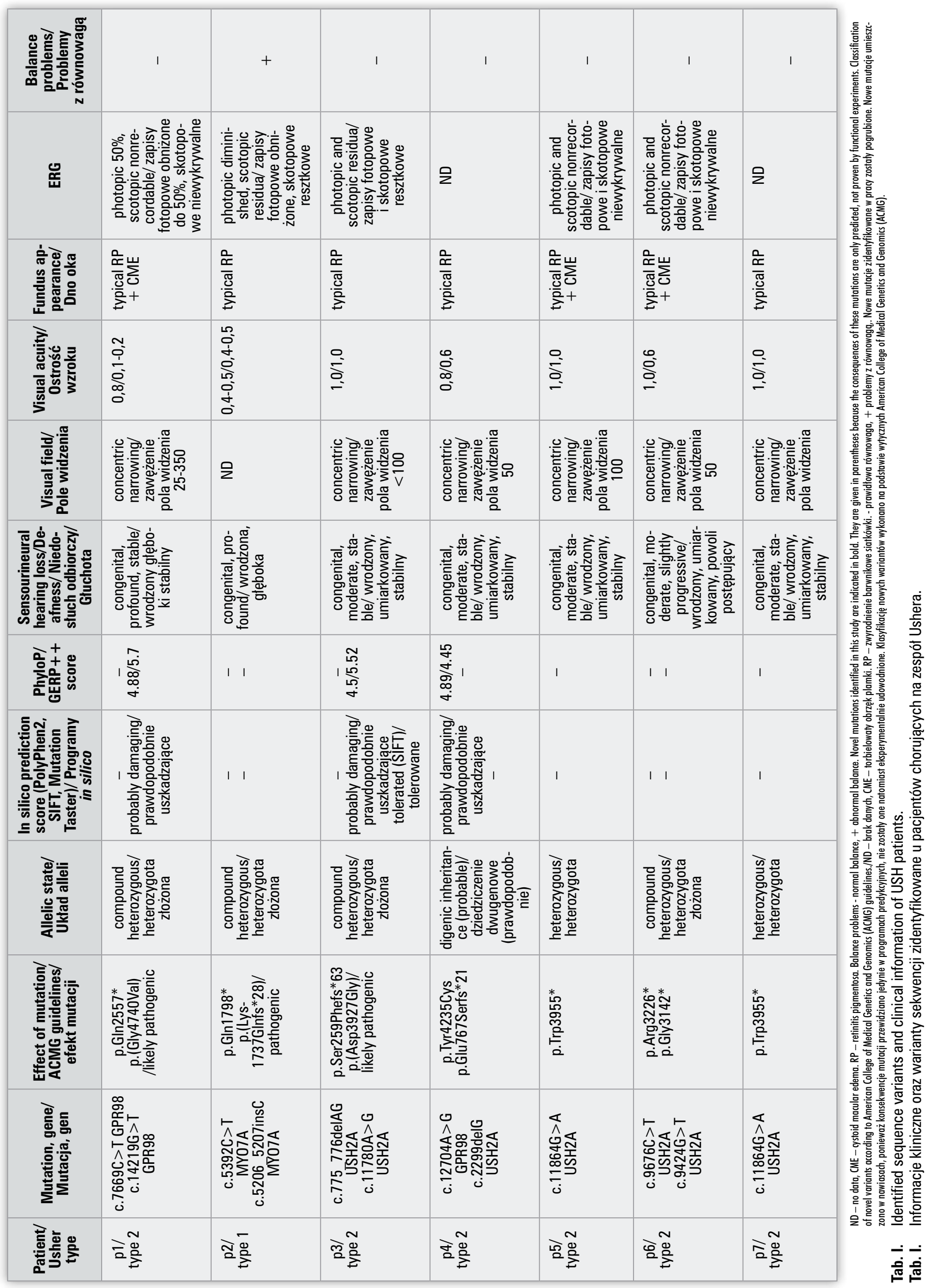


-intronic and intragenic deletions or duplications, only such methods as whole genome sequencing (WGS) or array CGH could be effective. Additional whole exome sequencing (WES) could be a good alternative in order to identify mutations in known or novel genes which are not included in the USH panel.

The effective method which enables a reliable molecular diagnosis of USH can improve genetic counseling contributing to earlier diagnosis in children, as well as pre-symptomatic USH2 and USH3 patients, which can be crucial for preventive or treatment modalities, which are being developed. Novel variants identified in this study expand the spectrum of mutations in USH related genes, thereby enhancing the current knowledge of USH heterogeneity, and further support the use of targeted NGS in genetic diagnosis of Usher syndrome.

\section{References}

1. Kimberling WJ, Hildebrand MS, Shearer AE, Jensen ML, Halder JA, Trzupek K, et al.: Frequency of Usher syndrome in two pediatric populations: Implications for genetic screening of deaf and hard of hearing children. Genet Med. 2010; 12: 512-516.

2. Riahi Z, Bonnet C, Zainine R, Lahbib S, Bouyacoub Y, Bechraoui $\mathrm{R}$, et al.: Whole exome sequencing identifies mutations in Usher syndrome genes in profoundly deaf Tunisian patients. PLoS One. 2015; 23: 0120584.

3. Ben-Rebeh I, Grati M, Bonnet C, Bouassida W, Hadjamor I, Ayadi $\mathrm{H}$, et al.: Genetic analysis of Tunisian families with Usher syndrome type 1: toward improving early molecular diagnosis. Mol Vis. 2016; 19: 827-835.

4. Bonnet C, Grati M, Marlin S, Levilliers J, Hardelin JP, Parodi M, et al.: Complete exon sequencing of all known Usher syndrome genes greatly improves molecular diagnosis. Orphanet $\mathrm{J}$ Rare Dis. 2011; 11: 6-21.

5. Roux AF, Faugère V, Vaché $C$, Baux $D$, Besnard $T$, Léonard $S$, et al.: Four-year follow-up of diagnostic service in USH1 patients. Invest Ophthalmol Vis Sci. 20118: 4063-4071.

6. Weston MD, Eudy JD, Fujita S, Yao S, Usami S, Cremers C, et al.: Genomic structure and identification of novel mutations in usherin, the gene responsible for Usher syndrome type Ila. Am J Hum Genet. 2000; 66: 1199-1210.

7. Le Quesne Stabej P, Saihan Z, Rangesh N, Steele-Stallard HB, Ambrose J, Coffey A, et al.: Comprehensive sequence analysis of nine Usher syndrome genes in the UK National Collaborative Usher Study. J Med Genet. 2012; 49: 27-36.

8. García-García G, Besnard T, Baux D, Vaché C, Aller E, Malcolm S, et al.: The contribution of GPR98 and DFNB31 genes to a Spanish Usher syndrome type 2 cohort. Mol Vis. 2013; 19: 367-373.

9. Yan D, Liu XZ: Genetics and pathological mechanisms of Usher syndrome. J Hum Genet. 2010 55: 327-335.

10. Joensuu T, Hamalainen R, Yuan B, Johnson C, Tegelberg S, Gasparini $\mathrm{P}$, et al:: Mutations in a novel gene with transmembrane domains underlie Usher syndrome type 3. Am J Hum Genet. 2001; 69: 673-684.

11. Puffenberger EG, Jinks RN, Sougnez C, Cibulskis K, Willert RA, Achilly NP, et al:: Genetic mapping and exome sequencing identify variants associated with five novel diseases. PLoS One. 20127: 28936.

12. Yoshimura $\mathrm{H}$, Oshikawa $\mathrm{C}$, Nakayama J, Moteki $\mathrm{H}$, Usami S: Identification of a novel CLRN1 gene mutation in Usher syndro- me type 3: two case reports. Ann Otol Rhinol Laryngol. 2015; 1: 94-99.

13. Richards S, Aziz N, Bale S, Bick D, Das S, Gastier-Foster J, et al.: Standards and guidelines for the interpretation of sequence variants: a joint consensus recommendation of the American College of Medical Genetics and Genomics and the Association for Molecular Pathology. Genetics in medicine: official journal of the American College of Medical Genetics. 2015; 17: 405-424.

14. Krawitz PM, Schiska D, Krüger U, Appelt S, Heinrich V, Parkhomchuk D, et al.: Screening for single nucleotide variants, small indels and exon deletions with a next-generation sequencing based gene panel approach for Usher syndrome. Mol Genet Genomic Med. 2014; 2: 393-401.

15. Besnard T, García-García G, Baux D, Vaché C, Faugère V, Larrieu $\mathrm{L}$, et al.: Experience of targeted Usher exome sequencing as a clinical test. Mol Genet Genomic Med. 2014; 2: 30-43.

16. Vozzi D, Aaspõllu A, Athanasakis E, Berto A, Fabretto A, Licastro $\mathrm{D}$, et al.: Molecular epidemiology of Usher syndrome in Italy. Mol Vis. 2011; 17: 1662-1668.

17. Bonnet C, El-Amraoui A: Usher syndrome (sensorineural deafness and retinitis pigmentosa): pathogenesis, molecular diagnosis and therapeutic approaches. Curr Opin Neurol. 2012; 25: 42-49.

18. Ebermann I, Scholl HP, Charbel Issa P, Becirovic E, Lamprecht J, Jurklies $\mathrm{B}$, et al.: A novel gene for Usher syndrome type 2: mutations in the long isoform of whirlin are associated with retinitis pigmentosa and sensorineural hearing loss. Hum Genet. 2007; 121: 203-211.

19. Hoefele J, Wolf MT, O'Toole JF, Otto EA, Schultheiss U, Dêschenes G, et al.: Evidence of oligogenic inheritance in nephronophthisis. J Am Soc Nephrol. 2007; 18: 2789-2795.

20. Zheng QY, Yan D, Ouyang XM, Du LL, Yu H, Chang B, et al.: Digenic inheritance of deafness caused by mutations in genes encoding cadherin 23 and protocadherin 15 in mice and humans. Hum Mol Genet. 2005; 14: 103-111.

21. García-García G, Aller $E$, Jaijo $T$, Aparisi MJ, Larrieu L, Faugère $\mathrm{V}$, et al.: Novel deletions involving the USH2A gene in patients with Usher syndrome and retinitis pigmentosa. Mol Vis. 2014; 20: $1398-410$.

22. Aparisi MJ, Aller E, Fuster-García C, García-García G, Rodrigo R, Vázquez-Manrique RP, et al.: Targeted next generation sequencing for molecular diagnosis of Usher syndrome. Orphanet J Rare Dis. 2014; 18, 9: 168.

23. Austin-Tse CA, Mandelker DL, Oza AM, Mason-Suares $H$, Rehm HL, et al.: Analysis of intragenic USH2A copy number variation unveils broad spectrum of unique and recurrent variants. Eur J Med Genet. 2018; 61: 621-626.

The paper was originally received 11.07.2018 (K0-00173-2018)/ Praca wpłynęła do Redakcji 11.07.2018 r. (KO-00173-2018)/ Accepted for publication 28.12.2018/

Zakwalifikowano do druku 28.12.2018 r.

Reprint requests to (Adres do korespondencji):

Anna Wawrocka, PhD

Department of Medical Genetics, Poznan University

of Medical Sciences

Rokietnicka 8

60-806 Poznan, Poland

e-mail: ania.wawrocka@gmail.com 